\title{
Depth-related timing of density band formation in Porites spp. corals from the Red Sea inferred from X-ray chronology and stable isotope composition
}

\author{
R. Klein ${ }^{1}$, J. Pätzold ${ }^{2}$, G. Wefer ${ }^{2}$, Y. Loya ${ }^{1}$ \\ ${ }^{1}$ Department of Zoology, Tel Aviv University, Ramat Aviv 69978, Israel \\ ${ }^{2}$ Geowissenschaften, Universität Bremen, Klagenfurter Str., W-2800 Bremen 33, Germany
}

\begin{abstract}
Skeletal density bands in scleractinian corals have been extensively used in the last 2 decades for environmental and palaeoenvironmental studies. Despite the great importance of coral banding in such studies, the environmental cues that control the timing of band deposition are poorly understood. Here we present a study based on stable isotopic composition and X-ray chronology of Porites spp. corals from shallow $(3 \mathrm{~m})$, intermediate $(30 \mathrm{~m})$ and deep $(51 \mathrm{~m})$ water in the Gulf of Eilat, Red Sea. The results indicate a depth-related timing of density band formation, with opposite patterns in shallow and deep water corals. These observations may play an important role in understanding environmental controls of density banding in corals.
\end{abstract}

The skeletal aragonite deposited by massive scleractinian reef corals is characterized by alternating bands of high and low density calcium carbonate (Knutson et al. 1972, Buddemeier et al. 1974, Buddemeier \& Kinzie 1976). This banding pattern is generally annual (Knutson et al. 1972) and has been used in the reconstruction of past and modern environments (Dodge \& Vaisnys 1975, Weber et al. 1975, Hudson et al. 1976 , Isdale 1984, Klein et al. 1990, Leder et al. 1991). Nevertheless, environmental factors controlling the banding pattern are still uncertain (Buddemeier \& Kinzie 1975, Highsmith 1979, Wellington \& Glynn 1983). A comparison of the chronology of density bands, detected from X-radiographs of coral slabs with their seasonal pattern of stable oxygen isotopic composition, provides a precise tool for timing their formation (Weber et al. 1975), due to the relationship between $\delta^{18} \mathrm{O}$ and temperature (Weber \& Woodhead 1972). A study based on such analysis was carried out on Porites spp. corals from the Gulf of Eilat, Red Sea.

In most cases, determination of the intra-annual timing of high (HD) or low (LD) density band formation was based on analysis of corals from shallow and intermediate water depths (down to $30 \mathrm{~m}$ ). In the present study, Porites spp. heads were collected from 3 depths: 3 (shallow), 30 (intermediate) and $51 \mathrm{~m}$ (deep) in the

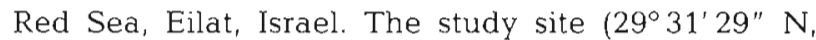
$34^{\circ} 56^{\prime} 34^{\prime \prime} \mathrm{E}$ ) is characterized by a fringing reef in shallow water, a steep slope covered with patch reefs down to $40 \mathrm{~m}$, and a moderate slope down to $70 \mathrm{~m}$, covered by a dense stand of soft and stony corals (Reiss \& Hottinger 1984). The depths of 3,30 and $51 \mathrm{~m}$ represent 3 different habitats, especially in terms of light availability for photosynthesis by zooxanthellae, the symbiotic algae living in association with the corals. That is, photosynthesis progressively decreases over the depth range 3 to $51 \mathrm{~m}$ (McCloskey \& Muscatine 1984, Muscatine et al. 1989).

The dried corals were sectioned to ca $6 \mathrm{~mm}$ thick slabs parallel to their growth axis and X-rayed to reveal their annual growth bands (Knutson et al. 1972). Vertical growth profiles exhibiting the most distinct growth bands, free of bioerosion, were detected from the X-ray images and selected for stable isotope measurements. In order to attain high resolution, carbonate samples for the stable isotope measurements were prepared in 2 different ways: (1) corals collected from the shallow and intermediate depths (high coral growth rate) were drilled along a vertical growth profile using a $0.5 \mathrm{~mm}$ diameter drill (Fig. 1a, b), and (2) corals from the deep reef (slow coral growth rate) were microsampled by removing (polishing) skeletal carbonate powder from the upper section, oriented in the direction of upward growth, using $200 \mu \mathrm{m}$ step increments (Fig. 1c). The number of sub-samples taken ranged from 6 to 12 per annual band (for details see also Fig. 2). 


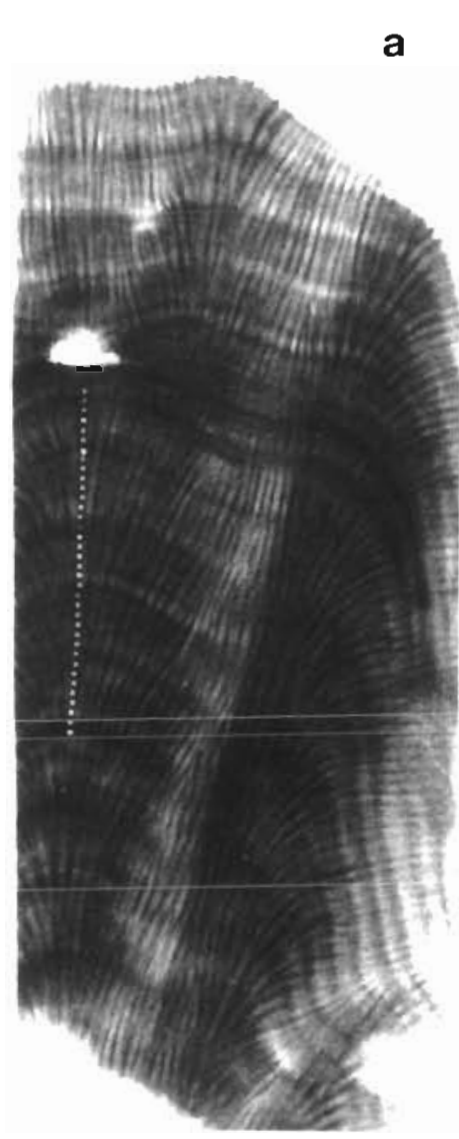

Fig. 1. Porites spp. X-radiographs of the 3 coral slabs from which subsamples for stable-isotope analysis were taken. (a) Sample S4, $3 \mathrm{~m}$ depth; (b) Sample MB30, $30 \mathrm{~m}$ depthi (c) Sample IS51, $51 \mathrm{~m}$ depth. The sampling scheme is presented in each image (see text for further details). The profiles for stable-isotope measurements were selected in accordance with their quality (i.e. distinct bands, avoiding traces of boring organisms or other disturbances), hence they represent different time series (specified in Fig. 2)

b

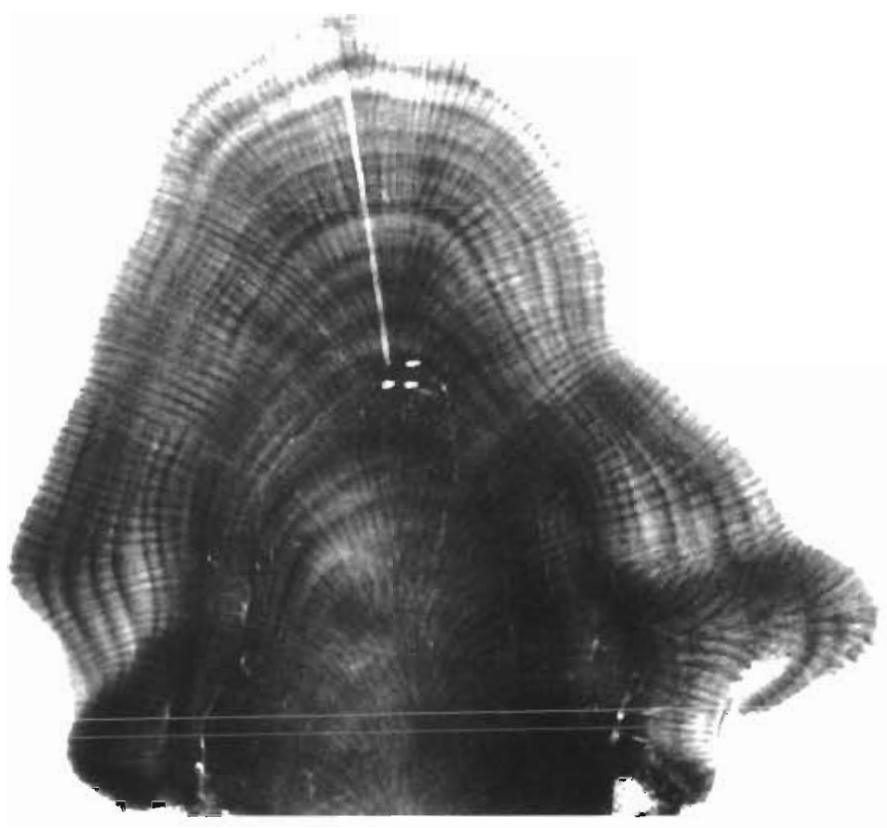

C
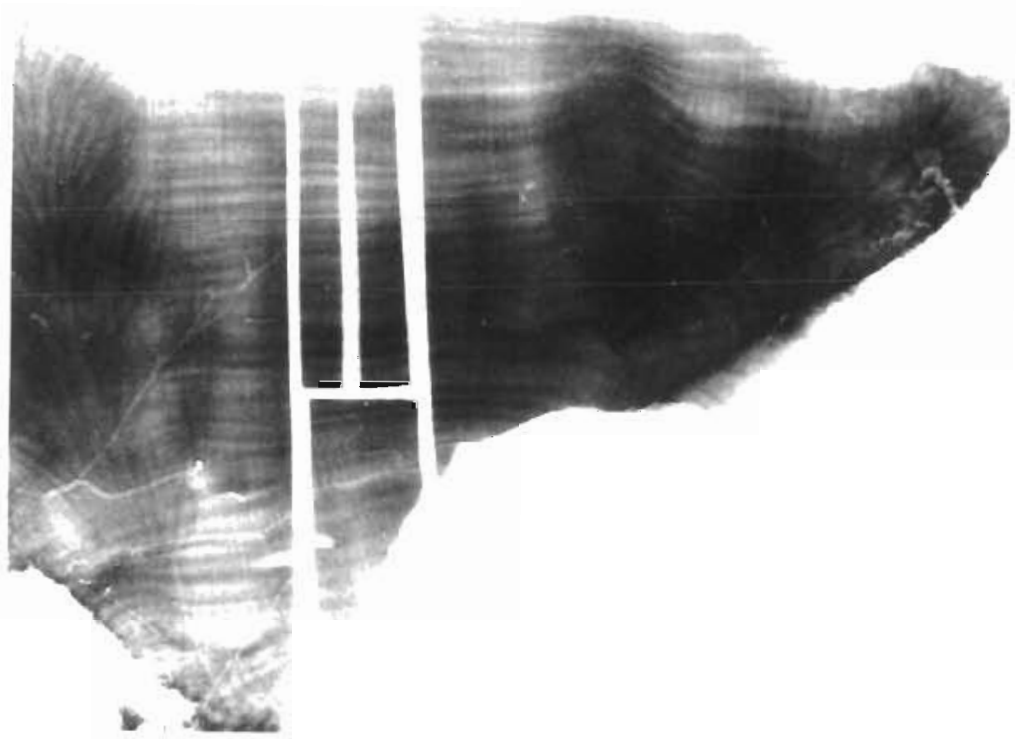

Fig. 2 summarizes optical density profiles (panels a to $c$ ) and stable isotope profiles (d to f) performed on the corals. Profiles in Fig. 2 (panels $d$ to f) show the stable carbon and oxygen isotopic compositions of the corals at 3,30 and $51 \mathrm{~m}$ depth, respectively. A pattern of annual periodicity was observed in both $\delta^{18} \mathrm{O}$ and $\delta^{13} \mathrm{C}$ values for the 3 colonies. Samples were ${ }^{18} \mathrm{O}$ depleted in the period of high water temperature (summer) and ${ }^{18} \mathrm{O}$ enriched in the period of low water temperature (winter), as expected from the known oxygen-isotope to temperature relationship (Epstein et al. 1953). The stable carbon isotopic composition responds to variations in light intensity through the photosynthetic activity of the symbiotic algae, where photosynthesis selectively removes ${ }^{12} \mathrm{CO}_{2}$, leading to higher ${ }^{13} \mathrm{C} /{ }^{12} \mathrm{C}$ ratios in DIC (dissolved inorganic carbon) and therefore also enriches the carbon isotope ratio of the coral skeleton (Weber \& Woodhead 1970 , Fairbanks \& Dodge 1979, Swart 1983). The negative $\delta^{13} \mathrm{C}$ maxima (lightest values) usually preceded the $\delta^{18} \mathrm{O}$ minima (Fig. $2 \mathrm{~d}$ to $\mathrm{f}$ ). In the Red Sea, there is a time lag between light intensity and seawater temperature, where sun irradiance maxima and minima precede temperature maxima and minima. Sun irradiance 


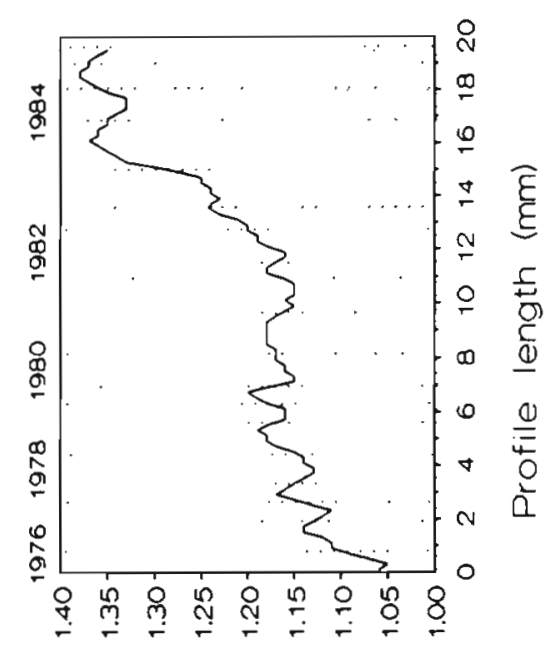

U

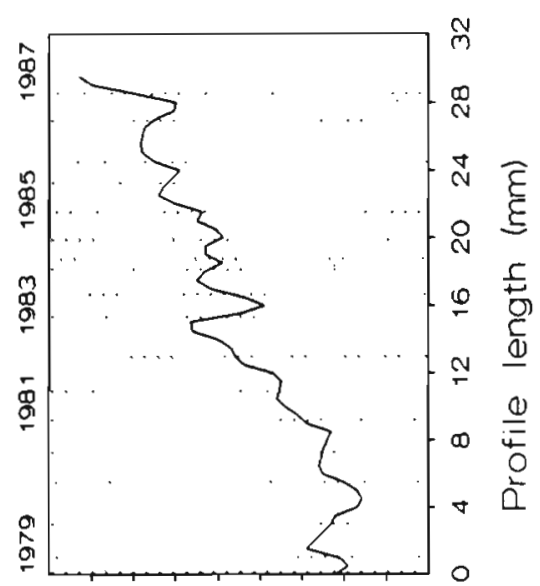

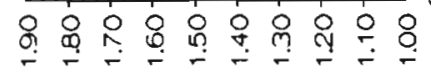

0

$0^{\circ} \mathrm{O}$

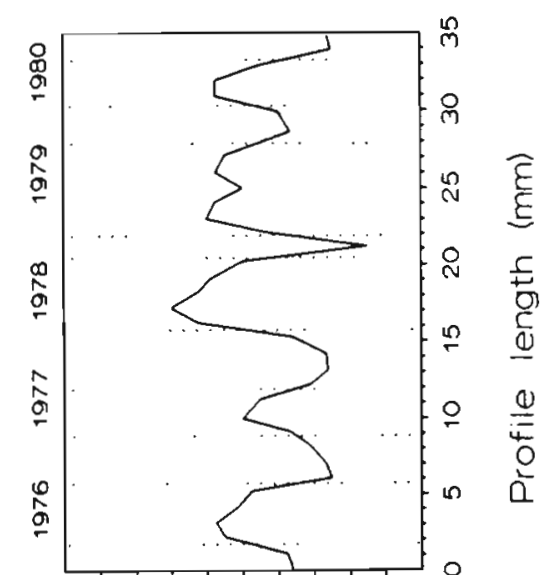

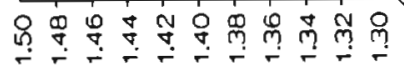

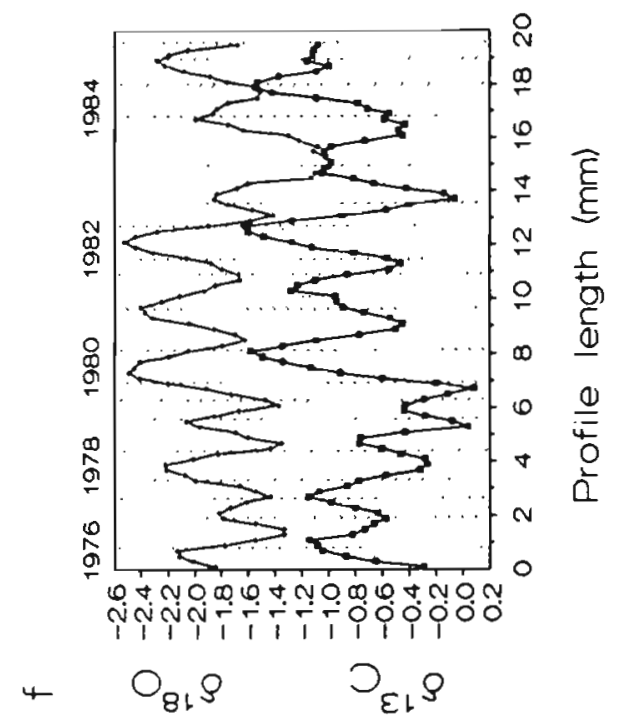

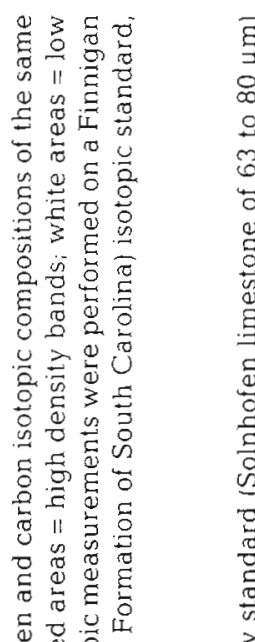

可

存要

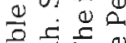

空合过

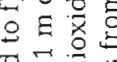

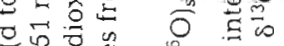

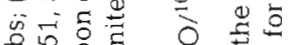

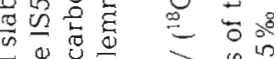

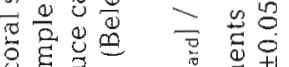

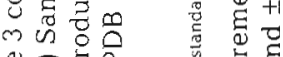

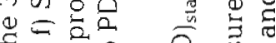

\pm 붕요

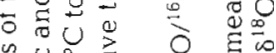

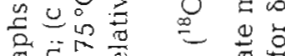

昰苋远 1

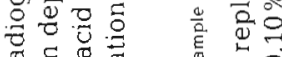

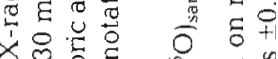

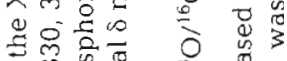

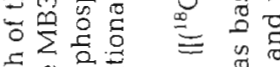

(1)

$\mathrm{O}_{81} \rho \quad \partial_{\varepsilon !} \Omega$

兽 을

됴용

इ웡

吕

证

要

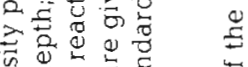

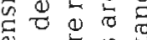

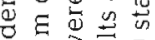

의 $3 \overrightarrow{3}$

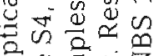

Oे@它它

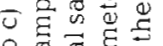

○元

- $\frac{0}{0} 80$

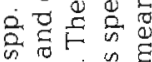

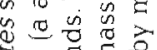

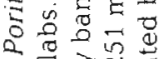

$2 \pi \geq \pi$

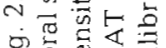

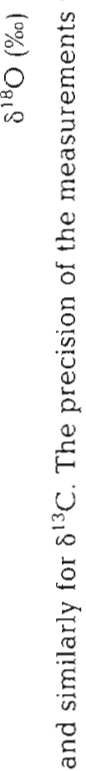


values reach their minima between December and January, while minimum seawater temperatures are recorded between February and March. The time lag between $\delta^{13} \mathrm{C}$ and $\delta^{18} \mathrm{O}$ reflects the time lag between these 2 environmental parameters in the Gulf of Eilat (Klein et al. 1992).

The stable oxygen isotope composition is of particular importance in this study as it is used to determine the intra-annual timing of band formation. The average intra-annual variations in $\delta^{18} \mathrm{O}$ for corals from 3,30 and $51 \mathrm{~m}$ were $0.8,1.1$ and $0.8 \%$, respectively. Based on the seasonal differences in seawater temperature (ca $5^{\circ} \mathrm{C}$ ), the differences in $\delta^{18} \mathrm{O}$ represent 70 to $100 \%$ of the expected difference, using Epstein's $\delta^{18} \mathrm{O}$ to temperature relationship (Epstein et al. 1953). The position of high density (HD) and low density (LD) bands was detected from optical density profiles run on each of the X-radiographs. The borderlines between HD bands and LD bands were marked as the density midway between maximum and minimum optical density values (Dodge \& Brass 1984) (Fig. 2a to c), and were then superimposed on the stable oxygen isotope curves (Fig. 2d to f) for determination of the intraannual timing of band deposition. Alternating shaded and white areas in Fig. 2 (a to f) represent the periods of HD and LD band deposition, respectively. The corals from the 3 water depths showed different patterns of band deposition times. These patterns gradually shifted from deposition of HD bands during winter and LD bands during summer at $3 \mathrm{~m}$ depth (Fig. 2d, see also Klein \& Loya 1991), through deposition of HD bands from late winter to early summer and LD bands from early summer to late winter at $30 \mathrm{~m}$ depth (Fig. 2e), to a deposition pattern of HD bands during summer and LD bands during winter at $51 \mathrm{~m}$ depth (Fig. 2f).

The pattern of density banding has been reported previously for shallow water colonies (ca $3 \mathrm{~m}$ depth) (Klein \& Loya 1991). Colonies that were collected during summer showed complete HD outermost bands or a transition to incipient LD bands, and vice versa for colonies that were collected during winter. In order to verify the major finding of opposite patterns of density band formation between shallow and deep water corals as obtained from the stable-isotope analysis (Fig. 2d, f), we examined 4 additional X-radiographs of coral samples from deep water (ca $50 \mathrm{~m}$ depth). Two of the deep water corals were collected during summer (June 1990) and 2 during winter (February 1993). Colonies that were collected during summer showed thin $\mathrm{HD}$ outermost bands (probably incipient) and colonies that were collected during winter showed incomplete LD outermost bands (compared to the previous year).

Although an exceptional pattern of banding variation in corals within one reef environment was reported (Lough \& Barnes 1990), most studies indicate that a uniform banding pattern in a coral population typifies a given reef locality (see Fairbanks \& Dodge 1979, Highsmith 1979, Wellington \& Glynn 1983, Scoffin et al. 1989 and others). It has been assumed that the factors responsible for coral banding operate the same way for all depths in all localities. Although light has been considered as one of the major factors controlling coral density banding, the nature and timing of skeletal band deposition in deep reef corals in extremely low light conditions have not been previously studied.

Seasonal variations in seawater temperature (Dodge \& Vaisnys 1975, Weber et al. 1975, Hudson et al. 1976), in light intensity (Buddemeier \& Kinzie 1975, Wellington \& Glynn 1983), a combination of both (Highsmith 1979, Schneider \& Smith 1982), water turbidity and sedimentation (Dodge \& Vaisnys 1975), and reproduction and nutrient availability (Wellington \& Glynn 1983) have been suggested to influence the formation of density bands. However, all these suggested factors still remain to be integrated in a general model explaining the mechanism of density band formation in corals.

Seasonal cycles in seawater temperature occur at all 3 water depths studied, and the water temperatures decreased only ca $1^{\circ} \mathrm{C}$ towards a depth of $51 \mathrm{~m}$ due to a weak summer thermocline (Paldor \& Anati 1979). In summer, during similar high water-temperatures (25 to $26^{\circ} \mathrm{C}$ ) in shallow and deep reef zones, individual corals deposited LD bands at $3 \mathrm{~m}$ and HD bands at $51 \mathrm{~m}$ depth. It appears that the seasonal variations in seawater temperature, which are clearly detected in the $\delta^{18} \mathrm{O}$ composition of the coral skeletons, are not responsible for the different density patterns at different water depths.

A marked decrease in light intensity occurs along the depth profile, where corals at a water depth of $51 \mathrm{~m}$ dwell in low light conditions $(<10 \%$ of the measured surface light values) (Reiss \& Hottinger 1984). The effect of reduced light on the width of the density bands can be seen easily. The average annual growth rates, measured as the distance between sequential stable oxygen minima (heavy isotopic compositions) in the $\delta^{18} \mathrm{O}$ curves, were $6.8,3.3$ and $2.0 \mathrm{~mm} \mathrm{yr}^{-1}$, for the corals from 3,30 and $51 \mathrm{~m}$ water depths, respectively. This marked decrease in the growth rate is attributed to the low light conditions, supporting the conclusions reached in other works (reviewed in Buddemeier \& Kinzie 1976).

The Gulf of Eilat is a northward extension of a desert-enclosed sea, and represents oligotrophic water conditions with a low concentration of nutrients (Reiss \& Hottinger 1984). Corals may derive their energy from photosynthetically translocated products fixed 
by their symbiotic algae (autotrophy), by feeding on demersal zooplankton (heterotrophy), or other allochthonous sources of carbon. It was suggested that corals living in the $50 \mathrm{~m}$ deep waters in the Gulf of Eilat may depend more on heterotrophic carbon and energy sources compared to shallow corals, due to the relatively low rates of photosynthesis (Muscatine et al. 1989). It was previously suggested that changes in skeletal density of Porites spp. corals from the Great Barrier Reef in Australia could be attributed to the observed cross-shelf heterotrophy-autotrophy gradient (Risk \& Sammarco 1991). It is possible that changes in the heterotrophy-autotrophy ratio along the depth profile in the reef water of Eilat may dictate the observed density banding patterns. Both the quantitative heterotrophy-autotrophy ratio and the role of light as major mechanisms underlying the density band patterns remain to be studied.

The 2 main types of band deposition patterns found in this study are similar to those found in the Galapagos corals (McConnaughey pers. comm.). The deep coral $(51 \mathrm{~m})$ laid down a dense skeleton with higher ${ }^{13} \mathrm{C}$ during the time of highest light intensity at Eilat (summer), similarly to McConnaughey's 'deep' coral $(17 \mathrm{~m})$ in the Galapagos Islands. The $3 \mathrm{~m}$ coral, and to a lesser extent the $30 \mathrm{~m}$ coral, laid down a dense skeleton during the time of lowest light intensity at Eilat (winter), similarly to McConnaughey's shallow water Porites spp. $(0 \mathrm{~m})$. The deep water 'crossover' in the deposition pattern occurred in much deeper water in the Gulf of Eilat than in the Galapagos. Bright sunshine and clear waters probably allow the shallow banding pattern to shift much deeper in the water column at Eilat than in the Galapagos, where low clouds and plankton-rich waters prevail over much of the year (McConnaughey pers. comm.).

It was recently stated that more attention should be given to the identification of general trends in timing of band formation and exceptions to these trends (Lough \& Barnes 1990). Our data suggest a gradual change in the intra-annual timing of band formation along a depth profile between 3 and $51 \mathrm{~m}$ at the coral reef in Eilat. This observation requires verification by examination of additional samples from other geographical areas, and with other species of band-forming corals. If this depth-related shift is a general phenomenon, it may have great value in further understanding the mechanism behind skeletal band formation, and deserves greater attention in future sclerochronological studies.

Acknowledgements. We thank A. Miroz and A. Abelson for their help in the fieldwork, and the Marine Laboratory at Eilat for the use of research facilities. All isotopic measure- ments were carried out at the stable-isotopic laboratory at Bremen University. Special thanks are due to $M$. Segl for performing the isotopic measurements. We would like to express our gratitude to P. Aharon, B. Brown, R. Dodge, T. McConnaughey, L. Muscatine, A. Szmant, M. Le Tissier and $\mathrm{S}$. Tudhope for their constructive comments on the manuscript. This study was partially supported by a MINERVA Award to R.K., and a grant from the National Council for Research and Development, Israel, and the Ministry of Science and Technology (BMFT) (MOST, Joint GermanIsraeli Research Program) and Marine Paleoclimate Project (BMFT 07KF002)

\section{LITERATURE CITED}

Buddemeier, R. W., Kinzie, R. A. (1975). The chronometric reliability of contemporary corals. In: Rosenberg, G. D., Runcorn, S. K. (eds.) Growth rhythms and the history of the earth's rotation. Wiley, London, p. 135-146

Buddemeier, R. W., Kinzie, R. A. (1976). Coral growth Oceanogr. mar. Biol. A. Rev. 14: 183-225

Buddemeier, R. W., Maragos, J. E, Knutson D. W. (1974). Radiographic studies of reef coral exoskeletons: rates and patterns of coral growth. J. exp. mar. Biol. Ecol. 14: 179-200

Dodge, R. E., Brass, G. W. (1984). Skeletal extension, density and calcification of the reef coral, Montastrea annularis: St. Croix, U.S. Virgin Islands. Bull. mar. Sci. 34(2): 288-307

Dodge, R. E., Vaisnys, J. R. (1975). Hermatypic coral growth banding as environmental recorder. Nature 258: 706-708

Epstein, S., Buchsbaum, R., Lowenstam, H. A., Urey, H. C. (1953). Revised carbonate-water isotopic temperature scale. Bull. geol. Soc. Am. 64: 1315-1325

Fairbanks, R. G., Dodge, R. E. (1979). Annual periodicity of the ${ }^{18} \mathrm{O} /{ }^{16} \mathrm{O}$ and ${ }^{13} \mathrm{C} /{ }^{12} \mathrm{C}$ ratios in the coral Montastrea anullaris. Geochim. Cosmochim. Acta 43; 1009-1020

Highsmith, R. C. J. (1979). Coral growth rates and environmental control of density banding. J. exp. mar. Biol. Ecol. 37: $105-125$

Hudson, J. H., Shinn, E. A., Halley, R. B., Lidz, B. (1976) Sclerochronology: a tool for interpreting past environments. Geology 4: 361-364

Isdale, P. J. (1984). Fluorescent bands in massive corals record centuries of coastal rainfall. Nature 310:578-579

Klein, R., Loya, Y (1991). Skeletal growth and density patterns of two Porites corals from the Gulf of Eilat, Red Sea. Mar. Ecol. Prog. Ser. 77: 253-259

Klein, R., Loya, Y., Gvirtzman, G., Isdale, P. J., Susic, M. (1990). Seasonal rainfall in Sinai Desert during the late Quaternary inferred from fluorescent bands in fossil corals. Nature 345: 145-147

Klein, R., Pätzold, J., Wefer, G., Loya, Y (1992). Seasonal variations in the stable isotopic composition and the skeletal density pattern of the coral Porites lobata (Gulf of Eilat, Red Sea). Mar. Biol. 112: 259-263

Knutson, D. W., Buddemeier, R. W., Smith, S. V. (1972). Coral chronometers: seasonal growth bands in reef corals. Science 177: 270-272

Leder, J. J., Szmant, A. M., Swart, P. K. (1991). The effect of prolonged 'bleaching' on the skeletal banding and stable isotopic composition in Montastrea annularis. Coral Reefs 10: $19-27$

Lough, J. M., Barnes, D. J. (1990). Intra-annual timing of density band formation of Porites corals from the central Great Barrier Reef. J. exp. mar. Biol. Ecol. 135: 35-57 
McCloskey, L. R., Muscatine, L. (1984). Production and respiration in the Red Sea coral Stylophora pistillata as a function of depth. Proc. R. Soc. B 222: 215-230

Muscatine, L., Porter, J W., Kaplan, I. R. (1989). Resource partitioning by reef corals as determined from stable isotope composition. Mar. Biol. 100: 185-193

Paldor, N., Anati, D. A. (1979). Seasonal variations of temperature and salinity in the Gulf of Eilat (Aqaba). Deep Sea Res. 26: 661-672

Reiss, Z., Hottinger, L. (1984). The Gulf of Aqaba. Ecological micropaleontology. Springer-Verlag, Berlin

Risk, M. J., Sammarco, P. W. (1991). Cross-shelf trends in skeletal density of the massive coral Porites lobata from the Great Barrier Reef. Mar Ecol. Prog. Ser. 69: 195-200

Schneider, R. C., Smith, S. V. (1982). Skeletal Sr content and density in Porites spp. in relation to environmental factors. Mar. Biol. 66: 121-131

This article was submitted to the editor
Scoffin, T. P., Tudhope, A. W., Brown, B. E. (1989). Fluorescent and skeletal density banding in Porites lutea from Papua New Guinea and Indonesia. Coral Reefs 7: 169-178

Swart, P. K. (1983). Carbon and oxygen isotope fractionation in scleractinian corals: a review. Earth-Sci. Rev. 19: 51-80

Weber, J. N., Deines, P., White, E. W., Weber, P. H. (1975), Seasonal high and low density bands in reef coral skeletons. Nature 255: 697-698

Weber, J. N., Woodhead, P. M. J. (1970). Carbon and oxygen isotope fractionation in the skeletal carbonate of reefbuilding corals. Chem. Geol. 6: 93-117

Weber, J. N., Woodhead, P. M. J. (1972). Temperature dependence of the oxygen-18 concentration in reef coral carbonates. J. geophys. Res. 77: 463-473

Wellington, G. M., Glynn, P. W. (1983). Environmental influences on skeletal banding in Eastern Pacific (Panama) corals. Coral Reefs 1: 215-222

Manuscript first received: December 11, 1992

Revised version accepted: March 31, 1993 